\title{
PARA UMA LEITURA FENOMENOLÓGICA DA HISTORICIDADE DO DIREITO
}

\section{FOR A PHENOMENOLOGICAL READING OF THE HISTORICITY OF LAW}

\author{
Paulo César Pinto de Oliveira ${ }^{1}$
}

\section{RESUMO}

O presente trabalho tem por objetivo acompanhar, por meio da corrente filosófica da fenomenologia, que atua aqui como suporte teórico do texto e se desenvolve através de uma revisão bibliográfica, o modo através do qual a história do direito desenvolve o seu discurso teórico. No interior da disciplina o que se observa não é apenas a exposição das teorias e metodologias históricas, ou a evolução do pensamento histórico sobre o direito ao longo do tempo, mas também a própria articulação temporal do fundamento do direito ou a temporalização do seu ser em meio à interpretação. Com base na hermenêutica filosófica de Gadamer, podemos concluir que uma história do direito genuinamente hermenêutica permite o acréscimo de ser do direito diante da retomada temporal dos temas e problemas, principalmente através da reformulação da teoria das fontes do direito.

Palavras-chave: História do Direito; Teorias da História Jurídica; Fenomenologia e Hermenêutica; Historicidade do Direito; Fontes do Direito e reformulação.

\begin{abstract}
The present work aims to accompany, through the philosophical current of phenomenology, which acts here as a theoretical support for the text and develops through a bibliographic review, the way in which the history of law develops its theoretical discourse. Within the discipline, what is observed is not only the exposure of historical theories and methodologies, or the evolution of historical thought about law over time, but also the temporal articulation of the foundation of law or the temporalization of its being in through interpretation. Based on Gadamer's philosophical hermeneutics, we can conclude that a genuinely hermeneutic history of law allows the addition of being in the face of the temporal resumption of themes and problems, mainly through the reformulation of the theory of the sources of law.
\end{abstract}

Key-words: History of Law; Theories of Legal History; Phenomenology and Hermeneutics; Historicity of Law; Sources of law and reformulation.

\footnotetext{
${ }^{1}$ Doutor em Filosofia do Direito - UFMG. Coordenador do Grupo de Pesquisa "Herethik - Hermenêutica, Retórica e Ética". Prof. Departamento de Direito - UFV. Universidade Federal de Viçosa, MG - Brasil. Lattes: http://lattes.cnpq.br/3102387105968854 E-mail: pclafaiete@hotmail.com
} 


\section{INTRODUÇÃO}

Como o próprio título de texto sugere, a história, em Nietzsche, é sempre útil à vida, mas, em algumas ocasiões, ela pode se demonstrar desvantajosa. Na Segunda Consideração Intempestiva - da utilidade e da desvantagem da história para a vida, o filósofo da Basileia nos adverte que precisamos da história não do mesmo modo que um passeante mimado no jardim do saber - a história é útil à vida, e nos faz ter apreço por ela, quando ela fomenta a vida e a ação em seu interior: quando, então, ela não permite o abandono confortável da vida em prol de seu embelezamento egoísta, ou a realização de uma ação covarde ou ruim (NIETZSCHE, 2003, p. 05). A história é digna de apreço e de consideração quando ela, assim, acentua a vitalidade, e não a estiola ou impede que a ação no interior da dinâmica vital se estabeleça. Ora, antes de tudo, o que a palavra vida aqui significa para Nietzsche? Através da análise de $O$ nascimento da tragédia, a vida é aquela que se estabelece entre as pulsões contraditórias do apolíneo e do dionisíaco, que representam, por sua vez, a constituição da individuação e da sua correlata dissolução (NIETZSCHE, 1992, p. 25). As imagens da pulsão poética de Nietzsche, na verdade, tentam reconciliar ou dar concretude a duas dimensões tidas por antagônicas na tradição filosófica - ser e devir. Com o apolíneo, a vida se mostra como aparência digna de ser afirmada em seu conteúdo ontológico próprio; com o dionisíaco, esta beleza se dissolve diante da necessidade de o devir enraizar-se (CASANOVA, 2003, p. X). Portanto, vida aponta aqui para a dinâmica de vir-a-ser da realidade, na relação que requisita continuamente, sob pena de serem eliminados concomitantemente, os dois terminais, ser e devir.

A dinâmica da vida, por sua vez, é temporal: a temporalidade é constitutiva da existência, sendo que passado, presente e futuro são co-pertencentes (HEIDEGGER, 2012, p. 887) - as ekstases temporais, na expressão de Heidegger, ou as formas do tempo, deixam ver que cada uma delas é de tal maneira que uma ultrapassa a si própria em direção à outra, ou seja, uma não é sem a outra (FIGAL, 2016, p. 77). A vida humana, assim, por ser marcada por uma temporalidade imanente, é histórica, daí Nietzsche afirmar que a história é sempre útil à vida. Contudo, para ela ser útil e ao mesmo vantajosa, o passado não pode aparecer como um entrave ao presente e nem como um elemento que irá obstaculizar o futuro. O passado deve ser incorporado ao presente para permitir que a vida seja fomentada, e uma história a serviço da vida, como adverte Casanova, é aquela que luta contra o controle científico do passado para 
que ele, plasticamente, seja apropriado no presente na forma do instante (CASANOVA, 2003, p. XI). Essa lida desvivificante com o passado é estabelecida pela metafísica, que trabalha em desfavor da vida quando cinge ou separa ser e devir, privilegiando o primeiro contra o segundo, além de defender o ser frente à aparência, o inteligível ao sensível, a substância face ao acidente, a verdade em relação ao erro e o repouso contra o movimento - a verdade, que aparece no interior do discurso metafísico, é marcada por um caráter ideal totalmente apartado da casuística do mundo fenomênico (CASANOVA, 2003, p. XIII). A metafísica, como conclui Casanova, tenta se libertar da realidade marcada pela transitoriedade rumo à estabilidade, que tornaria possível a verdade, mas sempre viu tal esforço ser condenado ao fracasso (CASANOVA, 2003, p. XIII). O problema da metafísica, portanto, não é apenas de índole teórica ou filosófica, mas de caráter vital, pois se refere às formas históricas de constituição de vivências.

A metafísica, ao promover a busca do ser frente ao devir, retira-se do campo das aparências, da mobilidade permanente que atesta as diferenças, para se recostar junto àquilo que é e sempre será. O discurso metafísico acompanha a abertura plena do ente na totalidade (HEIDEGGER, 2011, p. 35), a dinâmica de presentificação do ente presente à vista enquanto critério de verdade (CASANOVA, 2013, p. 248), e encontra à sua base a temporalidade e a historicidade, que se apoiam na questão do fundamento (HEIDEGGER, 1979, p. 313).

Há, portanto, uma relação ínsita entre vida, historicidade e fundamento, que requer um modo de abordagem que permita, ao mesmo tempo, que a história sirva à vida, ao incorporar o passado ao presente de maneira produtiva; que se veja, no presente, o fenômeno na riqueza que é dele; e que, ao mesmo tempo, essa relação entre passado e presente se desenvolva tendo em vista a própria historicidade do fundamento. Tarefa profundamente hercúlea, portanto.

O nosso interesse aqui se volta ao tratamento desta relação não de forma geral, mas sim através da tematização de um objeto específico, o direito, em sua dimensão histórica. Pensar a constituição histórica do direito no interior da vida aparece aqui como objetivo imediato deste trabalho. O pensamento jurídico, na maior parte das vezes, desenvolve as suas temáticas a partir da compartimentalização de suas informações por meio de suas chamadas "disciplinas": filosofia do direito, ciência do direito, história do direito ${ }^{2}$. Em todas elas há um tratamento

\footnotetext{
2 João Paulo Araújo faz uma interessante observação a respeito da divisão das disciplinas que se preocupam em abordar o direito enquanto objeto de conhecimento em sentido amplo - Teoria do Direito, Filosofia do Direito, História do Direito, Sociologia do Direito, Antropologia Jurídica: a diversidade de disciplinas deixa ver o fato, que causa acanhamento aos versados no jurídico, de que o direito se encontra sempre para além de leis ou até mesmo da justiça. Contudo, o interessante é que o universo da juridicidade vai se expandido para abarcar outros segmentos de saberes, mas sempre mantendo o genitivo objetivo. (ARAÚJO, 2018, p. 59).
} 
daquilo que convencionalmente se chama direito, por meio do pensar, no interior da história, que não só nos fornece uma reconstrução do jurídico, como também permite a articulação do seu próprio ser (OLIVEIRA, 2019, p. 349), ou o seu fundamento. A despeito de uma certa unidade de tarefa, nós desenvolveremos estas reflexões no interior da chamada história do direito, movidos pela desafiadora temática da reflexão acerca da formação da historicidade do direito, ou da historização de seus fundamentos constitutivos. Para tanto, a nossa abordagem se dará pelo seguinte itinerário: inicialmente, de forma breve, passaremos pela discussão a respeito da tarefa e da função da história do direito; em seguida, deteremos nossa atenção àquilo que fenomenologicamente se chama de direito, ou seja, tentaremos acompanhar o que se encontra em jogo intencionalmente no fenômeno do direito, procurando, sobretudo, perceber como o modo tradicional ou metafísico de reflexão a respeito do jurídico tematiza o fundamento de posição de regras ou normas obrigatórias; por fim, tentaremos perceber a importância da hermenêutica fenomenológica gadameriana para a história do direito, no que se refere à lida interpretativa com o fundamento do direito.

\section{A HISTÓRIA DO DIREITO E SEUS DESDOBRAMENTOS TEÓRICOS}

António Manuel Hespanha nos ensina que a história do direito tradicionalmente é apresentada como uma disciplina fundamental para a formação do jurista e de profissionais do direito em sentido amplo, mas também serve à justificação da legitimidade do poder político estabelecido e do fundamento de validade da ordem jurídica posta, sendo que, em algumas ocasiões, como se nota na Escola Histórica do direito, é a própria história do direito aquela que desenvolverá a fundação da juridicidade (HESPANHA, 2005, p. 24-5). A história do direito, assim, desenvolve o seu discurso tendo por objetivo acompanhar a constituição da ordem jurídica, consciente, de maneira metodológica, do caminho discursivo e do flanco teórico que precisa trilhar para tanto. No interior da história do direito encontram-se interligados os métodos de articulação do passado do discurso jurídico, como, também, a própria recomposição do direito no tempo, ou o atuar de sua historicidade. Partimos aqui da tese de que o direito não encontra o seu fundamento apenas em comandos, em decisões ou em práticas normativas, mas é composto e recomposto no interior do discurso histórico sobre ele. Como esclarece Harold Berman, a historicidade do direito está ligada à sua superioridade em relação às autoridades políticas, que só é garantida pela pluralidade de suas fontes, o único elemento que o protege 
dos malefícios do historicismo (BERMAN, 2006, p. 28). Pode-se afirmar, desse modo, que, no interior do discurso da história do direito encontram-se a realidade histórico-jurídica em sua articulação temporal, a historicidade, e o próprio conhecimento histórico da mesma, na forma de uma ciência histórica. Separar as duas instâncias é impossível, distingui-las é útil para aquilo que temos aqui como objetivo deste trabalho: deixar ver a historicidade do fundamento do direito para que sua história sirva ao presente.

O português, ao contrário, por exemplo, do alemão, não possui duas palavras distintas para se referir ao fenômeno histórico: Geschichte diz respeito à realidade efetivamente histórica, que articula a temporalidade por meio de suas ekstases, ao passo que Historie é afeta ao conhecimento histórico e às suas condições de possibilidade, à ciência da história, portanto (HEIDEGGER, 2012, p. 1025). Ao longo deste texto, quando nos referirmos à realidade histórica em movimento, articulando temporalidade, utilizaremos a expressão historicidade, e, ao nos referirmos à ciência histórica, simplesmente nos valeremos do termo história.

À base da palavra história se encontra tanto a ideia de uma experiência vital como também a narrativa em torno desta, que a reproduz em discurso. Koselleck nos afirma que reflexão a respeito da história humana se estabelece a partir do século XVIII, com Kant e Buffon, quando há a sua distinção em relação à história natural, que envolve o movimento dos astros, das estrelas, atrelado à contagem dos dias, dos meses, das estações e dos anos (KOSELLECK, 2014, p. 10). A aproximação entre história e natureza já era observada no mundo antigo, em que a análise do fluxo histórico se desenvolvia analogicamente ao ciclo biológico, apesar de as duas esferas estarem em oposição: a natureza é imortal, de pronto e de imediato; os homens, mortais, e, para garantirem posição na eternidade, precisam se destacar em feitos e palavras, agir em conformidade à natureza para sobreviverem ao devir (ARENDT, 2014, p. 78). No século XVIII, porém, a história passa a requisitar tratamento autônomo e diferenciado em relação à natureza, promovendo a própria temporalização do natural (KOSELLECK, 2014, p. 10). O século XVIII nos abre a pesquisa sobre o sentido da história, introduzindo a necessidade de se pensá-la filosoficamente (LÖWITH, 1991, p. 16); já o século XIX a toma em seu tratamento científico, indagando-se sobre a objetividade e o alcance do conhecimento histórico (ARENDT, 2014, p. 83).

O tratamento filosófico da história se desenvolve a partir da busca de um sentido que oriente e conceda finalidade aos fatos históricos particulares. Há, portanto, uma meta, um projeto, uma teleologia que envolve imanentemente os acontecimentos particulares, mas que 
acaba por transcendê-los, aninhando-os em um começo ou início conjecturado e em ponto decisivo ou de chegada (LÖWITH, 1991, p. 19). Löwith (1991, p. 16) ainda nos afirma que, apesar de a busca por uma teleologia imanente à história já se fazer presente no interior da teologia medieval, assentada na Providência Divina enquanto motor da história, e que se manifesta na ideia de escatologia, é com Voltaire que uma filosofia da história com bases racionais se estabelece, e encontra em Kant seus desdobramentos decisivos.

A filosofia da história de Kant representa o ponto de chegada do pensamento ilustrado, que se concretiza no gênero humano ao se conquistar a preponderância do racional sobre o irracional mediante os desdobramentos da vontade ou razão pura prática (KANT, 2008, p. 11), que, do ponto visto da humanidade em sua unidade total, atua como teleologia imanente à natureza (KANT, 2004, p. 04). Como se sabe, o criticismo deixou em evidência a limitação do conhecimento à fenomenalidade (KANT, 1985, p. 50 e segs.) - o próprio fenômeno é interiorização, na medida em que é objeto da subjetividade, ou do posicionamento do eu transcendental, pois nada mais é do que sensações recepcionadas pelas formas a priori da sensibilidade, espaço e tempo -, sendo que quando a subjetividade transcendental pretende pensar para além daquilo que se apresenta à sensibilidade, formam-se os juízos contraditórios ou antinomias/paralogismos da razão pura ${ }^{3}$, a ideia, que, no âmbito gnosiológico, atuam como elemento regulador do conhecimento sensível, mas que no plano do agir constituem a possibilidade da representação da lei moral e de uma metafísica dos costumes. $\mathrm{O}$ agir ético, por meio do qual máximas subjetivas e princípio objetivo da ação se encontram na condução pela vontade, realiza-se no sujeito moral, mas necessita do todo da humanidade para sua efetivação - daí a tese, sustentada por Kant em $O$ que é o Esclarecimento?, de que o uso público da razão precisa ser livre a todo instante para possibilitar sua efetivação entre os seres humanos e permitir o progresso do gênero enquanto todo (KANT, 2011, p. 26-7). Esse caminhar do desenvolvimento da essência moral do homem aparece em Kant como plano secreto ou teleologia interna da natureza, cuja forma de manifestação é a história (KANT, 2004, p. 04-5), e que tem como vértice a ideia de um criador ou a ideia prática de um legislador moral universal para todos os deveres humanos, como o autor da lei moral que em nós habita - Deus (KANT, 1993, p. 91). A história em Kant é desdobramento da moralidade, sendo que a perfeição moral, postulado necessário da razão prática, é um ideal apenas na sociedade que a consume

\footnotetext{
${ }^{3}$ São as por Kant denominadas miragens da extensão do entendimento puro, desenvolvidas na dialética transcendental. (KANT, 1985, p. 295-6)
} 
definitivamente através da universalidade do estado direito (HERRERO, 1991, p. 139), rumo ao republicanismo puro e ao projeto de uma paz perpétua (KANT, 2008, p. 11 e segs.).

O projeto da filosofia da história ilustrada é recepcionado e levado adiante pelo idealismo hegeliano, que estende o transcendental para o interior do campo de jogo da história. Hegel também pensa o curso da história como evolução, mas agora promovida pela unidade entre a certeza do sujeito e a verdade do objeto (HEGEL, 2012, p. 39) - o Espírito, que se dá na dialética entre figuras (formas exemplares de aparição no Espírito na história de maneira não-cronológica, e sim de acordo com o nível de importância para o processo de formação da consciência) e momentos, estágios percorridos para que apareça a unidade das próprias figuras, verdadeira lógica imanente ao saber rumo ao absoluto (LIMA VAZ, 2012, p. 15). Diferentemente de Kant, em que a história se desdobra na forma de um projeto conjectural, em Hegel o Espírito tem transparência em relação a si mesmo no interior do tempo histórico efetivamente transcorrido, unificando o caminho histórico percorrido e o ponto de chegada da trajetória, a ideia. Com isso, é possível perceber a lógica da história e na história através da unidade entre forma e conteúdo, ou seja, entre pensar e pensamento pensado (SALGADO, 1996, p. 71). A ideia é o conteúdo pensado na história que se apresenta como forma lógica, e, justamente por ser lógica, a história eleva o particular ao plano de universal ao concebê-lo como uma etapa ou momento do próprio caminhar do Espírito e do desenvolver-se pleno da ideia na forma do sistema, superando-se cisões unilaterais, como a entre sujeito e objeto (Fenomenologia do Espírito), razão e natureza (Enciclopédia das Ciências Filosóficas), liberdade individual e lei (Filosofia do Direito), razão teórica e razão prática (Ciência da Lógica) - (SALGADO, 1996, p. 69). Todavia, como adverte Casanova, o fenômeno histórico particular é sacrificado em prol da efetividade - "não a miríade infinita de determinações particulares, mas as determinações unificadoras de tal infinitude" (CASANOVA, 2013, p. 58), sacrifício esse que encontra na astúcia da razão um dos modos de caracterização do negativo na história. O sacrifício do particular na sua submissão ao movimento do Espírito é veemente contestado pelo historicismo alemão, que marca não somente a ruptura, no século XIX, com as filosofias da história que procuravam encadear os fenômenos particulares a um movimento teleológico universal, como também permite o aparecimento de um tratamento científicometodológico da história.

A relação entre totalidade, vida e história é tematizada de perto pelo historicismo alemão, todavia por meio de características bem próprias. $\mathrm{O}$ historicismo nasce com a pretensão 
de valorizar o evento histórico particular na sua riqueza peculiar e no aspecto multifacetado que lhe é próprio. Para José Carlos Reis, podem ser apontadas como principais características do historicismo a descoberta da história enquanto objeto de conhecimento específico, assim como da atitude do historiador, com técnicas e modos de abordagem do passado delineados marca a ciência histórica moderna, portanto; fenômenos naturais e históricos são diversos, requerendo diversos mecanismos de estudos; todos os fenômenos humanos se dão no fluxo da história, o que implica em dizer que o homem é passado, vem do passado, forma-se a partir dele; o passado ressoa ao presente - a história mais ou menos adequada que a vida faz de si mesma (REIS, 2003, p. 10-11). Reis ainda afirma que o historicismo, através da rejeição radical das filosofias da história iluminista e hegeliana, vê as relações entre história e filosofia se inverterem: é a filosofia que se revela histórica, é ela que se mostra influenciada e subordinada às suas condições históricas - a história não se submeteria a nenhum a priori (REIS, 2004, p. 09-10).

Isso, por outro lado, não implica em dizer que se abandona a tese do sentido da história ou a visualização de uma teleologia imanente ao fluxo dos eventos. Baseado em Herder, para quem cada época histórica tem seu valor particular, o historicismo alemão, em seus três notáveis representantes, Leopold von Ranke, Gustav Droysen e Wilhelm Dilthey, concebe que o sentido do todo histórico se manifesta nos fenômenos históricos particulares, que são articulados e manifestam o todo da vida. Em Ranke, há decisões históricas particulares dos espíritos originais que intervêm autonomamente na luta das ideias e das potências do mundo, que se destacam e articulam em si o nexo histórico. Os fenômenos da vida histórica são compreendidos como manifestações do todo da vida através do mergulho não-conceitual, uma espécie de autoapagamento racional, daquele que se dedica à compreensão na própria dinâmica de desenvolvimento do evento (GADAMER, 2011, p. 287 [215]).

Partindo da mesma tese de Vico de que somente é possível o conhecimento do mundo histórico por serem genuínas expressões vitais, Droysen, por outro lado, apoia-se em uma metodologia para a reconstrução do sentido histórico, em que o observador se dirige ao fato de forma neutra, esquecendo-se enquanto tal para não contaminar o observado. Da mesma maneira em que as ciências naturais obtiveram o êxito investigativo nelas visualizado pela obstinação metodológica, as ciências históricas também devem seguir previamente o procedimento de investigação antes de a investigação ela mesma se constituir, e esses passos são palmilhados pela distância entre estudioso e estudado, cuja pedra de toque se assenta na reconstrução neutra 
do fato histórico a partir das fontes que se encontram à disposição do pesquisador (GRONDIN, 1999, p. 141). Trata-se de uma historiografia, portanto, denominada por Gadamer de consciência histórica - à medida que se conhece historicamente um fato a consciência se autoconhece (GADAMER, 2011, p. 316 [239]) - de forma que as humanidades se veem historicamente mediadas, mas requisitam um método forjado no interior das ciências naturais: a reelaboração dos nexos explicativos do fato histórico de maneira neutra.

Em Dilthey, a relação entre ciências, métodos e história surge resgatando temas do pensamento de Droysen, mas agora voltada para a construção de um método específico das ciências humanas, como também com a pretensão de desenvolver uma crítica da razão histórica. As ciências, em franca autonomização e especialização ao longo do século XIX, despontam como aquelas capazes de apresentar conhecimento rigoroso e seguro justamente por se sustentarem em métodos previamente concebidos. As ciências naturais passam a ser visualizadas como as habilitadas a conduzir os processos investigativos e produzir resultados com pretensão de universalidade. Todavia, a despeito da pretensa segurança, segundo Dilthey, as ciências naturais são abstratas, a-históricas ou desvivificantes (DILTHEY, 2010, p. 72), ou seja, retiram o fenômeno do mundo da vida em que ele se apresenta: elas posicionam um fenômeno no espaço e no tempo e procuram reconstruir as relações causais que permitem explicar o seu modo de aparição. A ilusão que permeia as ciências naturais reside no obscurecimento do nexo histórico que está presente em suas investigações, procedimentos e resultados - um cientista, um farmacêutico, v.g., ao desenvolver uma pesquisa pontual não percebe que aquilo que por ele é analisado é uma requisição do tempo histórico em que ele se encontra, requisição essa que se retrai no interior das redes referencias da investigação (CASANOVA, 2010, p. 10). Cabe às humanidades, por outro lado, a tarefa de reinserir os fenômenos no todo da vida história, trazendo à presença a co-pertinência entre história e fatos particulares - lançar luz sobre os nexos histórico-estruturais refletidos em cada particularidade. É a isso que Dilthey denomina de compreensão - rearticular o particular com o universal, fato e vida histórica (DILTHEY, 2010, p. 194). A compreensão é o verdadeiro método de desenvolvimento não só da ciência histórica, mas também das humanidades em geral, e é por meio dela que fenômeno e vida são rearticulados em seu todo.

O modo pelo qual Dilthey concebe a compreensão como via de autonomia das ciências reside na relação de co-pertencimento entre vida e vivências. Vida significa aqui a unidade físico-espiritual presente em todos os fenômenos: é a complexidade que envolve elementos 
materiais, físicos, linguísticos, histórico e psíquicos transmitidos pela tradição (CASANOVA, 2010, p. 12). A vida, ponto de partida da filosofia para Dilthey, encontra-se intimamente ligada à época. Para o filósofo, ao se existir em um tempo histórico específico, imediatamente herdamse as concreções históricas desse tempo, as expressões da vida, que se abatem sobre os indivíduos de forma inquebrantável (DILTHEY, 2010, p. 109). A vida, enquanto unidade de fenômenos psíquico-espirituais, congrega em si a medida do nexo histórico. O todo da vida se manifesta por meio das vivências humanas, ou do homem enquanto ser vivencial, ou seja, o homem imediatamente se liga à vida histórica por meio de suas vivências, são elas o dado mais imediato (DILTHEY, 2010, p. 03), e elas se somam umas às outras na unidade da vida no transcurso do tempo (DILTHEY, 2010, p. 99). Como já se disse, as ciências humanas buscam a rearticulação do nexo do particular com o todo da vida histórica por meio da compreensão. Todavia, é impossível a reconstrução discursiva ou intelectual do todo da vida histórica sob pena de ter-se que passar por cada uma de suas expressões. Daí Dilthey tomar como materialidade básica da vida as vivências, que são os dados mais imediatos, mais particulares, mas que apontam diretamente para a vida - o homem carrega em si o conjunto de nexos vitais que perpassam suas vivências, e há em todos os homens uma espécie de comunhão em relação ao nexo vital-estrutural. Isso quer dizer que há uma empatia necessária entre os indivíduos que brota do fato de eles se reconhecerem como co-pertencentes a uma época: as vivências não são tão diversas quanto parecem ser empiricamente porque se vive na mesma época. Nós não somos tão diversos como se acreditamos. Compreender significa aproximar eu e tu, mostrar a nossa proximidade temporal, eliminando-se o fosso que nos separa - é revivenciar o outro no eu (DILTHEY, 2010, p. 102), o eu no tu.

O que aparece no interior da construção filosófica do historicismo alemão é a tentativa de desenvolvimento de uma ciência histórica, uma historiografia, que tem projeto, objetivo e método de trabalho bem delineados. O historicismo almeja a reconstrução objetiva, total e neutra do fenômeno histórico orientado a partir da busca dos nexos histórico-causais (inclusive em Dilthey, pois a compreensão é o método por excelência das humanidades, seguindo-se a mesma tentativa da hermenêutica clássica do romantismo alemão - o método como categoria de desenvolvimento da compreensão), que permitiriam a articulação conjunta de uma vivência ou de um fenômeno particular ao todo da vida histórica. Dessa forma, são tenazes marcantes do historicismo a configuração de uma ciência historiográfica positiva e o peso conformador 
do passado, que é invocado na justificação do presente. Essas duas características são centrais para se pensar o modo como a história do direito se constituiu a partir do século XIX.

A história, na forma de uma ciência historiográfica, que se vale de chave teórica e de estrutura metodológica próprias para a tematização dos objetos, segundo Ricardo Marcelo Fonseca $^{4}$, é desenvolvida nos moldes de um positivismo dos fatos históricos no século XIX, com o apego à objetividade da realidade exterior, capaz de ser apreendida de maneira neutra, em meio aos documentos que são as suas fontes, e de ser reconstruída, na forma de narrativas isentas e correspondentes aos dados, pelo esforço do historiador (FONSECA, 2012, p. 52-3). Esse modo de abordar a história a partir de sua positividade, tomando-se o passado como um fato que é passível de ser identificado por meio de fontes, sobretudo de natureza documental, é transmitido à ciência e à história do direito do século XIX com apoio das codificações, do ponto de vista histórico-político, e, do ponto de vista filosófico, amparado nos desdobramentos da filosofia do direito hegeliana - por meio da primeira, o direito passa a ser visto como aquele se recolhe dos códigos, verdadeiros elementos de posição da razão jurídica, ou ponto de chegada dos jusracionalismos modernos (GOYARD-FABRE, 2007, p. 114); por meio da segunda, a efetivação da liberdade se dá no interior do Estado de Direito, que encontra na constituição e no direito escrito o modo de realização do universal-concreto do saber da liberdade e do próprio agir livre consciente de si (SALGADO, 2006, p. 02). Esse modo de identificação entre direito e direito posto, que encontrou nas codificações, sobretudo as francesas, o apoio necessário, chega aos territórios germânicos, inicialmente com Gustavo Hugo, para depois encontrar em Savigny o ponto máximo de desenvolvimento. Rejeitando a necessidade e a conveniência de uma codificação nos moldes franceses para a Alemanha, como se via na conhecida discussão com Thibaut (SAVIGNY, 1946), Savigny pretende trabalhar a positividade jurídica através do resgate da tradição cultural alemã, encarnada em suas práticas consuetudinárias - o propalado espírito do povo. A partir do jurista, abrem-se dois modos de desentranhamento dessa tradição, o romanista e o germanista. Para o primeiro, que é àquele a que se filia Savigny, o espírito do povo se mostra no direito romano compilado pelo imperador Justiniano e que foi recepcionado nos territórios germânicos desde 1500 (CAENEGEM, 2000, p. 220), ao passo que para a vertente germanista, desenvolvida sob a influência do romantismo alemão pelos ex-alunos de Savigny, Jacob e Wilhelm Grimm, o espírito do povo se manifestaria nos documentos, nas leis

\footnotetext{
${ }^{4} \mathrm{O}$ autor faz a distinção entre ciência histórica, teoria da história e metodologia histórica, cujas características peculiares não poderiam ser aqui reproduzidas em sua totalidade. (FONSECA, 2012, p. 29)
} 
e nos costumes germânicos e eclesiásticos que se desenvolveram desde a Alta Idade Média (SCHIOPPA, 2014, p. 357).

Savigny pretende retomar o direito romano de Justiniano que chegou aos territórios germânicos durante a Idade Média através de uma forma atualizada. Sob a influência do classicismo alemão, os eruditos e estudiosos do direito romano pretendiam resgatar o texto original das fontes romanas, afastando eventuais sobreposições de termos e expressões aos originais dos jurisconsultos e magistrados por seus intérpretes, inclusive pelo próprio Justiniano: os classicistas pretendiam escapar das chamadas interpolações, adulterações interpretativas dos textos jurídicos originais (KELLY, 2010, p. 427). A procura dos textos originais, entretanto, motiva-se pelo propósito de construção, por parte dos professores eruditos, de conceitos gerais, categorias e institutos que já se encontram presentes no interior das fontes romanas, mas que necessitavam do exame da razão para virem à superfície. O que se pretende afirmar é que Savigny tem em mira a formação de um sistema de direito romano atualizado pelo método jusracionalista (SCHIOPPA, 2014, p. 358), o Sistema de Direito Romano Atual (SAVIGNY, 1878). À base da metodologia de Savigny se congregam, portanto, positividade jurídica e arquitetônica racional, formando-se um direito professoral ou dos eruditos.

Ricardo Marcelo Fonseca nos afirma que as principais influências do historicismo sobre a historiografia positivista do século XIX se manifestam por meio de uma história das fontes e da dogmática (FONSECA, 2012, p. 63-4). Por meio da primeira observa-se uma suposta evolução do direito rumo à positividade jurídica, sobretudo a estatal, ao passo que, pela segunda, vislumbra-se a imagem da evolução do próprio direito, que se desenvolveria a partir do mundo antigo, passando pelo direito romano e pelas suas recepções na Europa, tal como um progresso natural, progressivo e linear. Para Thomas Duve, o papel de Savigny e da Escola Histórica do Direito para a construção da tese da evolução progressiva do jurídico, ou o metadiscurso sobre a evolução do direito, é fundamental. Por meio de Savigny, o direito romano é elevado ao nível do solo comum da juridicidade, e sua recepção doutrinária representou a atualização da ratio iuris, legando dois caminhos indeléveis à história do direito europeu: o primeiro, pelo qual a história das instituições romanas serviu de orientação à visão do direito enquanto fenômeno social mais amplo, trabalhada pelas Jurisprudências sociológicas do século XX; e o segundo, pelo qual a história dos institutos e dogmas jurídicos romanos serviu de referencial orientador para as codificações europeias (DUVE, 2015, p. 383-412, p. 405). 
A continuidade do passado, enquanto conformador justificativo do presente, traço marcante do historicismo alemão, é transmitido à historiografia jurídica do século XIX através da fórmula da evolução natural ou científica do direito, em que se nota que o saber jurídico do presente se apoia nas categorias recebidas do passado, que são expostas à superfície pela técnica jurídica da recepção, comum entre os glosadores, os comentadores e a pandectística alemã. Pela recepção, os doutrinadores conseguiam se debruçar sobre as fontes romanas e delas extrair os princípios imutáveis de uma razão jurídica, uma espécie de ficção que teria a meta de demonstrar que o sentido das normas e dos conceitos jurídicos do presente são os mesmos empregados nos textos do passado, ou, pelo menos, os mesmos vigentes nos contextos originários de produção de textos (HESPANHA, 2005, p. 55-6). A imagem da continuidade é a responsável, segundo Ricardo Marcelo Fonseca (FONSECA, 2012, p. 62), pela presença das chamadas introduções históricas dos textos das obras de dogmática jurídica, que têm a pretensão de demonstrar que aquele instituto ora analisado é o ponto de chegada de uma sedimentação racional que se desenvolveu há tempos, como também de atuar como instrumento diletante demonstrativo da erudição dos autores do direito. A crítica apresentada por Nietzsche ao historicismo se torna útil, uma vez mais, agora voltada à história do direito: o historicismo, pelo excesso do histórico, serve como peça de erudição que constrange o presente e impede sua vitaliciedade ao submetê-lo ao molde do passado.

As críticas à ideia de atemporalidade ou de continuidade evolutiva da historiografia jurídica positiva foram várias. António Manuel Hespanha, por exemplo, informa que a partir dos anos 1970, através da revista Ius Commune, do Instituto Max Planck de História do Direito de Frankfurt, verificou-se a tentativa de historicizar a história do direito, ressaltando-se a necessidade de ruptura e de fragmentação históricas no interior do seu discurso teórico (HESPANHA, 2005, p. 58-9). A tendência seria a de transportar as inovações metodológicas da Escola dos Annales francesa para a história do direito, em que prevaleceria, em detrimento à continuidade, a valorização dos contextos sociais concretos e específicos dos fenômenos jurídicos. Assim, abandona-se o finalismo evolucionista ao se enraizar o direito nas complexas e plurais relações sociais, prevalecendo não o monismo do discurso jurídico estatal, mas sim a polifonia dos múltiplos atores sociais e dos diversos discursos de poder (HESPANHA, 2005, p. 62 e segs.). Outra crítica apresentada ao modelo de continuidade provém da fabulosa e inspirada obra de Paolo Grossi e de todos os seus discípulos da Escola Florentina da História 
do Direito ${ }^{5}$, que levam adiante a assimilação das teses da Escola dos Annales pela história do direito. Para Grossi, o direito não pode se restringir ao conjunto de normas que formalmente limitam o devir social, nem ao conjunto de regras estabelecidas pelo detentor do poder constituído, nem mesmo se constrói pela continuidade evolutiva superficial de seus institutos, mas se encontra ligado ao nível mais profundo da civilização humana: ao prudente conhecimento das técnicas criadas por legisladores, juízes notários, doutores e particulares, sedimentadas no reticulado não escrito das mentalidades jurídicas, essa força invisível, impalpável, porém incisiva, que aflora nas dimensões antropológicas dos costumes jurídicos (GROSSI, 2014, p. 07).

Na esteira da crítica promovida pela Escola Florentina à historiografia tradicional do direito, Pietro Costa, aluno de Paolo Grossi, critica a própria estrutura metodológica da historiografia, que acreditava descrever os fatos históricos tal como eles se deram, pois, para o autor, o historiador nunca se encontra perante fatos, mas apenas perante testemunhos, pegadas. O historiador, ao entrar em contato com objetos materiais, deles recebe sinais que não permitem o contato direto com a realidade objetiva, mas sim a construção de um discurso sobre ela pela via dos indícios. Daí os fatos serem, de pronto, discursos, que, por sua vez, receberam o discurso do historiador, formando um discurso sobre o discurso. Pietro Costa, conclui que a historiografia não é descrição, mas sim interpretação; não é apreensão, mas atribuição de sentidos e de significados. A história do direito trata-se, portanto, de hermenêutica (COSTA, 2010, p. 20-21).

Do que expusemos até aqui, podemos concluir que a história do direito vai paulatinamente percebendo que a realidade exterior do direito, a ser recebida e analisada pelo seu historiador, não existe, de pronto e de imediato, mas é construída significativamente pelo seu historiador, como salienta Pietro Costa. Isso implica em dizer que não só as regras jurídicas, mas o próprio fundamento do direito é recorrentemente historizado, e não estabelecido de antemão. Contudo, a posição de Pietro Costa a respeito da história do direito, pelo autor mesmo denominada de hermenêutica, ainda permanece como uma visão teórica, que hipostasia o ser do direito, trabalhando no interior de uma teoria e não de uma filosofia do direito. Para que a história do direito desenvolva uma lida interpretativa com o ser do direito de forma radical, é

\footnotetext{
${ }^{5}$ A respeito, vale a pena a leitura da apresentação promovida pelo Arno Dal Ri Júnior à obra de Paolo Grossi (DAL RI JÚNIOR, 2010, p. IX-XXVII).
} 
preciso acompanhar o modo pelo qual o direito pode se desenvolver, enquanto fenômeno intencional.

\section{O FENÔMENO DIREITO E O SEU FUNDAMENTO}

Para que possamos seguir adiante e tematizarmos a relação entre a história do direito e a sua historicidade, é preciso recuar e voltarmos a já corriqueira questão do pensamento jurídico, que, por outro lado, sempre requisita uma vez mais a sua proposição: o que é o direito? Contudo, não queremos aqui, de imediato, nos orientar por uma vertente teórico-científicofilosófica, pelo menos de saída, que balizaria nosso questionar. Antes de tudo, é preciso ter em vista o que se dá com o próprio fenômeno do direito ${ }^{6}$, tal como ele o é abordado pela fenomenologia.

Com Edmund Husserl aprendemos que a fenomenologia é um modo de pensar caracterizado pelo acompanhamento descritivo do aparecimento dos fenômenos. A fenomenologia, é, antes de tudo, ciência dos fenômenos. Fenômeno, por sua vez, segundo Heidegger, é aquilo que se mostra em si mesmo e por si mesmo (HEIDEGGER, 2012, p. 119). Ao se afirmar que a fenomenologia é uma modalidade de pensamento que se guia pelos fenômenos, o que Husserl pretende é questionar a tese natural do filosofar, que pressupõe a realidade natural corrente do mundo exterior (HUSSERL, 2012, p. 12), como também intenta se contrapor às hipostasias positivistas ou psicologistas (HUSSERL, s/d, p. 41), realistas ou idealistas (CASANOVA, 2013, p. 78), que consideram o ser do fenômeno para além do seu campo de aparição - tomam o ser do fenômeno de forma exterior à própria fenomenalidade.

Se o pensamento se guia pelo fenômeno em seu campo de manifestação, não é mais possível se sustentarem oposições que sempre marcaram a história da filosofia: aparência e realidade efetiva, essência e existência, mundo ideal e mundo real. Contudo, como chama a atenção Dan Zahavi, todo o aparecimento é aparecimento para alguém (ZAHAVI, 2019, p. 18), e tal fato não passou despercebido a Husserl: a consciência, que se encontra à base dos fenômenos, é intencional, e isso implica em dizer que a consciência é um fluxo de vivências em curso (HUSSERL, 2012, p. 296), conjunto de atos, e não mais um bloco monolítico, como pensado pela filosofia moderna, cujo modo de ser é o da saída de si. Os atos da consciência são intencionais (intendere - tendem a), ou seja, projetam-se extensivamente, e, em meio a esse

\footnotetext{
${ }^{6}$ Como é promovido, por exemplo, por João Paulo Medeiros Araújo. (ARAÚJO, 2018, p. 24 e segs.)
} 
projetar, ocorre a autoformação de objetos que são correlatos a esse movimento de saída de si. Intencionalidade é o conceito que realça o fato de que quando um ato de consciência se estabelece, ao mesmo tempo, de maneira co-originária e não sucessiva, forma-se um correlato a esse ato de maneira imediata. Há, portanto, uma remissão de um a outro de pronto, de consciência ao mundo da consciência, e é nessa remissão que se constituem os objetos correlatos - a consciência não posiciona o objeto ou apreende a essência objetiva, e o sim o objeto se autoconstitui na relação estabelecida com a consciência. Uma vez que se tem em mente a remissão co-originária entre consciência e objeto correlato, o que a fenomenologia ressalta é justamente a necessidade de se colocar perante essa estrutura intencional e acompanhar descritivamente esse movimento de constituição conjunta de ato e correlato, de modo que quando essa descrição se pauta pela coisa em questão, o que se constitui em meio à relação intencional não pode ser negado: dito de uma forma mais clara, como a formação dos objetos correlatos não depende da subjetividade, ou seja, não é a consciência que posiciona esses objetos, essa objetividade não pode ser negada. A fenomenologia parte da suspensão do conhecimento natural do mundo empírico - a époche - para que se sonde a imanência de sua vida, que permitiria ver os campos intencionais em sua autoevidência (HUSSERL, s/d, p. 34). Daí a fenomenologia ser encarada como ciência rigorosa, de caráter transcendental, pois o que aparece é a própria dinâmica de realização da consciência e de seus objetos correlatos em sua gênese.

Na mesma medida em que a fenomenologia se trata de uma filosofia transcendental que coloca entre parênteses a tese da existência natural da realidade efetiva, ela possui como meta relocar essências na existência, o que demanda a presença do próprio mundo como espaço em que o filosofar se desenvolve: a fenomenologia deve pensar a relação entre homem e mundo a partir de sua factidade, como adverte Merleau-Ponty (2015, p.01). Para que a fenomenologia possa, de forma rigorosa, voltar às coisas tais como elas são, ou deixar ver a partir de si mesmos os fenômenos originários, deve ela ultrapassar as barreiras da consciência intencional, acompanhando o índice remissivo e radical em que as coisas se dão de maneira genuína, rumo ao mundo fático-sedimentado. É esse o esforço da filosofia heideggeriana, tematizar a relação intencional entre existência e mundo, ou estender a intencionalidade para além da relação consciência-correlato.

Em Heidegger, a existência é intencional: existir é lançar-se junto ao campo de objetos correlatos, ao mundo histórico sedimentado. Por isso Heidegger se vale da expressão ser-aí 
para se remeter à existência humana, ressaltando o seu modo de ser. $\mathrm{O}$ homem, de pronto e de saída, é marcado por uma indeterminação ou por uma nadidade essencial ${ }^{7}$ : não há uma essência humana, a que poderia ser subsumida a existência cotidiana, que indicaria a ideia de homem ou de humanidade. Daí não ser possível demarcar a existência por meio de categorias ou de conceitos, como ente racional, ente que se comunica, animal político. Ser um ser-aí significa ser marcado pelo caráter de possibilidade ou de poder-ser (HEIDEGGER, 2012, p. 141), já que, de imediato, não se é nada, pela ausência de essências. Ser-aí é uma estrutura (FIGAL, 2005, p. 68) ou um a priori performativo (CASANOVA, 2017, p. 45), que retrata o modo de ser do homem, marcado pela intencionalidade - existir é literalmente ek-sistir ou mover-se para fora, como se nota na junção do prefixo - ek - (para fora) e do radical -stemi (mover-se) (CASANOVA, 2017, p. 37). Contudo, diferentemente de Husserl, a intencionalidade heideggeriana aponta para a extensão da existência para o mundo: a possibilidade é correlata da nadidade originária do ser-aí, e se realiza concretamente em um mundo fático sedimentado em que o ser-aí já se encontra jogado ou de pronto inserido. Ser um ser-aí significa ser ser-nomundo (HEIDEGGER, 2012, p. 169), conquistar-se em meio à facticidade. Da mesma maneira que ser-aí, mundo não é uma categoria ou conceito, mas uma estrutura que é co-originária à existência. Mundo, ou facticidade, é o nexo estrutural mais abrangente, o horizonte de manifestabilidade dos entes enquanto tais na totalidade, ou, em outras palavras, campo histórico de possibilidade específicas (CASANOVA, 2017, p. 47). Mundo não é uma coisa dentre outras, mas, por ser horizonte de manifestação dos entes enquanto entes, está em todo lugar e em lugar algum. Como então, vê-lo? Há pouco afirmávamos que a fenomenologia pretende suspender o acesso teórico ou por hipostasias aos entes - logo, não se alcança o mundo por meio de teorias, e sim acompanhando os entes intramundanos que aparecem (CASANOVA, 2017, p. 61). Um ente sempre aparece a partir da totalidade significativa - mundo, o conjunto de campos de sentido historicamente constituídos que permitem que os entes, na lida prática ${ }^{8}$, sejam como são, de modo familiar.

A despeito do vocabulário denso e da complexidade das estruturas filosóficas, a fenomenologia sempre centras as suas atenções ao fenômeno, procurando, meticulosa e cuidadosamente acompanhar o seu próprio acontecimento, o aparecer, que requisita o mundo,

\footnotetext{
${ }^{7}$ Heidegger (2012, p. 139): "essência do ser-aí reside em sua existência”.

${ }^{8}$ Daí Heidegger iniciar a tematização da mundaneidade do mundo por meio dos utensílios, no §15, de Ser e tempo, pois os entes intramundanos aparecem para o ser-aí não como entes dotados de essências que podem ser apreendidas por faculdades cognitivas, mas sim como instrumentos para serem utilizados. (HEIDEGGER, 2012)
} 
enquanto totalidade de sentidos estruturados historicamente, e permite que os significados que orientam nossos comportamentos práticos ou lidas teóricas se desenvolvam enquanto tais. Ao mesmo tempo, se seguirmos o que desenvolvemos nos parágrafos anteriores em relação à estrutura intencional, poderemos perceber que todo o questionar já se movimenta em uma estrutura circular (HEIDEGGER, 2012, p. 641) que permite que o questionado apareça em si e por si, já que o mundo é, antes de tudo, abertura do ente na totalidade.

Tal fato não poderia ser diverso com o fenômeno direito. Quando se questiona a respeito do ser do direito, todo o questionamento se movimenta em meio aos modos tradicionais de se indagar a respeito do jurídico, que intencionalmente apontam para as vias de caracterização e de produção de normas ou regras, as chamadas fontes do direito. A pergunta "o que é o direito" encontra-se atrelada, historicamente, à resposta "o direito são as suas fontes" (SCHIOPPA, 2014 , p. 07), enquanto atos e fatos que produzem normas (BOBBIO, 1995, p. 45). Os campos de sentido e de significado sedimentados no interior de uma tradição são estruturados na forma de redes referenciais complexas, que atuam através de indicações de algo a algo (HEIDEGGER, 2012, p. 211). Os entes intramundanos, portanto, aparecem na totalidade significativa ${ }^{9}$ através $^{2}$ das estruturas prévias da interpretação: uma posição prévia, que permite uma visão prévia que destaca o ente dos demais, levando à uma conceptualidade prévia, que se enunciará nos discursos sobre os entes (HEIDEGGER, 2012, p. 429). No nosso caso, a pergunta "o que é direito?" nos remete, como dito, às suas fontes, que por sua vez, indicam as opções teóricas da tradição ao abordar o fenômeno - a questão das fontes se apoia estruturalmente na necessidade de se conjugarem justiça e segurança em meio a normas (SCHIOPPA, 2014, p. 08). Por sua vez, o dístico "justiça e segurança” nos remete à contraposição teórica justo-natural e justo-convencional, que atuam como fundamentos de produção de regras ou normas (BOBBIO, 1995, p. 15). Como afirma João Paulo Araújo, se direcionamos o olhar à história do pensamento jurídico, observamos que de Platão a Kelsen o pensar sobre as leis e a ordem correta para os homens trouxe consigo sempre o problema da medida desta correção:

\footnotetext{
9 "Nós preparamos o café da manhã ao acordarmos. Para tanto, a circunvisão precisa descobrir a cada vez o utensílio adequado para o uso: primeiro, a cafeteira vem ao nosso encontro, e, então, a lata com o pó de café, em seguida, o filtro, a tomada que liga a cafeteira, o botão para que a água comece a ferver até o café coado ficar pronto. Durante todo esse preparo, um sentido está sustentando a lida circunvisiva. Nunca se toma simplesmente café, mas se toma café em virtude da necessidade de se manter desperto depois de uma noite mal dormida, em virtude da pausa que o café promove no trabalho, etc. Este sentido, por outro lado, é sempre previamente compreendido e é ele que torna possível a atualização interpretativa de cada possibilidade como possibilidade". (CASANOVA, 2017, p. 186)
} 
Para além da existência de uma determinada posição ordenadora, de uma ordem, todo o pensamento ocidental que se lançou ao problema da normatividade trouxe consigo a necessidade de um fundamento daquilo mesmo para o que uma determinada ordem precisa se dirigir. Esse telos que é, a um só tempo, direção e fundamento, foi concebido como Justiça. A "justiça” aparece, no interior da tradição, como o correlato originário do "fenômeno jurídico" (Grifos nossos) (ARAÚJO, 2018, p. 37).

O pensamento jurídico, desenvolvido por meio de suas diversas disciplinas - filosofia do direito, ciência do direito, história do direito -, constituiu-se sempre à busca do fundamento radical do direito (SALGADO, 1996, p. 13), que garantiria a sua condição de possibilidade, ou seja, zelaria pelo próprio ser do direito. Esta posição, todavia, merece ser analisada com cuidado.

A filosofia, desde a procura grega pela arché, também se dedica à busca do fundamento da realidade, do ser dos entes em geral. Contudo, o pensamento grego, segundo Heidegger, parte da presença dos entes para se indagar a respeito do ser em geral (HEIDEGGER, 2012, p. 33), estabelecendo-se, assim, a metafísica como ontologia. Metafísica, como chama a atenção Casanova, é literalmente a transcendência do ente rumo à entidade. $\mathrm{O}$ ente, para ser idêntico a si próprio, não pode sucumbir ao devir, deve, assim, permanecer para ser. Ao afirmar o ente a partir da sua estabilidade e de sua presença e o ser como a própria entidade, a metafísica acaba por confundir o ser do ente com a presença constante (CASANOVA, 2013, p. 282), ou conceber o ser do ente como o fundamento máximo da presentidade dos entes presentes, como fundamento inconcusso (CASANOVA, 2013, p. 284). Heidegger, na fase de seu pensamento conhecida como a viragem, a partir dos anos de 1930, foca a sua atenção, sobretudo, para deixar clara a diferença fundamental entre ser e ente. Casanova adverte que a ontologias tradicionais incorrem no erro de acreditar que, ao se indagarem a respeito do "o que é o ente?", poderiam encontrar a essência do ser. Com o pensamento tardio de Heidegger, a pergunta adequada seria “como se alcança o fazer-se essência do ser?” (CASANOVA, 2013, p. 286), que é respondida por um elemento essencial do pensamento heideggeriano dos anos 1930 - "acontecimento apropriador" (HEIDEGGER, 2015, p. 31). Não é nosso objetivo imediato acompanhar de perto o que se encontra em jogo com a filosofia do acontecimento apropriador, mas, de uma forma breve, poderíamos dizer que ele se refere à essenciação do ser, que permite que o ente seja. Tal acontecimento implica um duplo movimento de desvelamento e retração:

O ser se essência na medida em que se doa como determinação do ente na totalidade, mas ao mesmo tempo detém sua infinita diferença, de modo que, nessa determinação mesma, surge um aceno à retração do ser, impedindo uma plena 
identificação entre o ser e a determinação do ente. Toda determinação do ser do ente na totalidade se mostra, portanto, uma determinação possível, histórica e, por isto, em última instância infundada. $\mathrm{O}$ ente representaria, neste sentido, o limite do conhecimento e da linguagem, enquanto o ser permaneceria incessantemente em seu espaço abissal e inatingível. (CASANOVA, 2013, p. 289)

O que se destaca por meio do acontecimento apropriador heideggeriano é justamente o acontecimento histórico do ser, que estabelece medidas epocais específicas com a abertura do ente na totalidade, como fundamento, mas o ser se recolhe, na diferença, não se confundindo com o fundamento estabelecido. Exatamente por isso ser não é fundamento, e todo o fundamento correlato à abertura do ente na totalidade é ele mesmo histórico. O acontecimento apropriador destaca não a descoberta do fundamento, mas sim a própria fundação do fundado (CASANOVA, 2013, p. 286). A metafísica toma o fundado historicamente como fundamento último, confundindo-o com o próprio ser. A reunião do fundamento histórico estabelecido no interior do acontecimento de ser e daquilo que a partir dele se desdobra é abrangida pelo conceito de época: "Época equivale a uma epoché, a uma retração do ser em proveito do ente: eidos platônico, ousia aristotélica, sujeito cartesiano como res cogitans, metamorfoseado em vontade no idealismo germânico e, finalmente, em vontade de poder no pensamento nietzschiano" (NUNES, 2013, p. 95).

A partir do pensamento tardio heideggeriano, podemos perceber que tudo o que se movimenta no interior de uma época encontra-se atrelado ao fundamento histórico estabelecido, fundamento esse também ele mesmo histórico, transitório. A tarefa do pensamento, segundo Heidegger, é justamente se colocar no lugar da guarda, da manutenção do acontecimento apropriador, de atenção a ele, de zelar pela manutenção da própria mobilidade histórica do mundo.

Gadamer, por sua vez, simplifica (quase às raias do simplório) a tese heideggeriana ao afirmar que a historização do fundamento, que permitiria a articulação temporal do ser, seria promovida pela mobilidade história dos horizontes de sentido através da interpretação, que permitiria acréscimo de ser ao interpretado no interior da chamada "fusão de horizontes". A hermenêutica filosófica fenomenológica apresenta um modo diverso de articular historicidade e ser, que poderia ser transposto ao próprio pensamento jurídico. 


\section{A HERMENÊUTICA FILOSÓFICA E A HISTORICIDADE DO FUNDAMENTO}

Conforme o que havíamos aduzido, o pensamento histórico sobre o direito, realizado em suas diversas disciplinas, sobretudo na aqui em destaque, a história do direito, realiza sua abordagem expositiva a partir de opções teóricas ou metodológicas, que deixam ver suas posições a respeito do que é o conhecimento histórico, qual é o seu objeto e a que se destina a sua finalidade, bem como, ao desenvolver a sua articulação discursiva, permite a historicidade do que se encontra em jogo no interior do discurso, ou possibilita a reconfiguração do ser ou do fundamento do direito. Apesar de Pietro Costa, com precisão, referir-se à função da história do direito como interpretativa ou hermenêutica, o historiador do direito, como o mesmo reconhece, movimenta-se no interior de uma teoria do método, ou no interior de uma ciência da interpretação. A hermenêutica gadameriana permite que se encontre a necessidade de atenção ao desenvolvimento histórico dos discursos sobre o direito, do ponto de vista científico, como também possibilita a historicidade do fundamento ou do ser do direito concomitantemente ao discurso sobre ele, ou, na expressão gadameriana, na lida interpretativa com a coisa em questão no diálogo.

A hermenêutica filosófica de Hans-Georg Gadamer surge com a pretensão de retomar, antes de tudo, o projeto da hermenêutica clássica, romântica e historicista, procurando agora superar os problemas do método por meio do qual ambas articulam a compreensão e o aparecimento do sentido através da fenomenologia husserliana e heideggeriana. Gadamer, assim, propõe-se a pensar decisivamente o nexo que permite a íntima conexão do particular com o universal, ao mesmo tempo em que esse mesmo nexo estrutural se forma também ele historicamente. Para superar as deficiências do método, Gadamer vale-se da intencionalidade husserliana como elemento característico da tematização indissociável entre visada e visado, e do projeto ontológico-fenomenológico heideggeriano para estender o intencional ao campo de constituição histórica do mundo.

A hermenêutica filosófica tem por finalidade deixar em evidência a compreensão como traço estrutural do mundo. Isto quer dizer que todas as relações que se travam no interior do mundo histórico sedimentado são compreensivas porque são mediadas pelos campos de sentido tradicionalmente formados e legados pela chamada história efeitual, que torna possível a compreensão em seu caráter universal. A propalada verdade dos processos históricos é aquela que se apresenta não mais na forma de fenômenos particulares submetidos a regras universais, 
avaliados na díade verdadeiro ou falso (GADAMER, 2011, p. 31 [03]), mas sim se nota no campo paradigmático da experiência do clássico (GADAMER, 2011, p. 378 [290]), fenômeno que se expande no tempo conservando-se a si mesmo em meio à sua diferenciação. A hermenêutica filosófica, assim, tem na história efeitual seu ponto marcante. História efeitual é a unidade entre a realidade histórica do nosso ser e, ao mesmo tempo, a consciência dessa mesma realidade. Com ela, Gadamer, hegelianamente, quer ressaltar o automovimento formativo dos processos históricos que produzem campos de sentido sedimentados, as précompreensões ou a tradição, como também a própria consciência do elemento que determina historicamente o nosso modo de ser, e, ao mesmo, que essa autoconsciência é, também ela, formada pela história efeitual.

O estar-presente diante de uma determinada configuração de sentido tradicional representa o que Gadamer (2011, p. 399-400 [307-8]) denomina horizonte hermenêutico: é a situação ou posição particular diante de uma determinada configuração de sentido da história efeitual. Compreender, assim, representa o esclarecimento acerca de uma imagem ou campo de sentido da tradição em meio a sua recepção no presente - é a checagem do horizonte de partida e o de chegada da tradição: a fusão de horizontes (GADAMER, 2011, p. 405 [311]). Para Gadamer, a compreensão contribui para a formação do ser do compreendido ou do interpretado, uma vez que não há ser para além de sua articulação relacional no processo histórico. As imagens da tradição se articulam na interpretação e ganham ser nesse encontro: "interpretação é um recriar (Nachschaffen), mas esse recriar não segue um ato criativo precedente, mas sim a figura de uma obra criada, que o intérprete deve apresentar segundo o sentido que encontrou aí" (GADAMER, 2011, p. 176 [125]). Gadamer, dessa forma, pensa a intencionalidade fenomenológica na relação entre a dinâmica da tradição e o intérprete na fusão de horizontes.

Do que até agora aqui dissemos, fica patente que a circularidade interpretativa, elemento que tanto está presente na hermenêutica clássica quanto na hermenêutica da facticidade heideggeriana, é peça fundamental para Gadamer, pois ela permite ver que o nosso acesso às coisas é sempre promovido pelo como hermenêutico, ou pela mediação da capa de preconceitos do mundo. Ao mesmo tempo, a hermenêutica filosófica chama a atenção para a autoformação de medidas históricas que se impõem no acontecimento da compreensão, medidas essas que podem não ser contestadas no caráter objetivo que é o delas, nem ser afastadas por métodos construídos por uma subjetividade racional - é a isso que Gadamer denomina verdade. No entanto, isso não implica em dizer que a história nos interpela definitivamente de um modo que 
ficamos adstritos de forma inaderredável ao que vem do passado. A filosofia em Gadamer exerce seu ofício interpretativamente: a interpretação, na recepção dos construtos tradicionais transmitidos pela História efeitual, abre o espaço, no questionamento acerca dessas mesmas imagens ou na pergunta “o que é a coisa?”, permite que ela se diga na relação estabelecida entre interpretação e interpretado.

A coisa de que se fala historicamente se apresenta em meio à interpretação, permitindose a correção conjunta de uma pela outra. O que se quer dizer é que a imagem do passado, no horizonte de saída, é recepcionada em sua chegada no interior da interpretação, e nessa mediação conjunta de um pelo outro é possível a reconfiguração do seu ser. A fusão de horizontes aponta para a possibilidade de correção conjunta de interpretação e de interpretado, pois a intencionalidade remissiva que se forma entre elas permite acréscimo de ser à imagem tradicional, que tanto admite que o construto do passado continue a ostentar sua conformação inicial, como também é possível que adquira uma imagem diversa no encontro interpretativo. Com a hermenêutica aprendemos que o ser de algo se forma na relação, o que, por outro lado, não significa dizer que ele é apenas relação, sob pena de cair-se no fantasma do relativismo.

O que está em jogo para a hermenêutica é um modo de experiência em que fenômenos não se sujeitam ao controle de regras: a experiência histórica, da arte e da filosofia, esclarecida da sua própria dinâmica temporal. A verdade da tradição, por meio da qual medidas no passado chegam ao presente e podem experimentar recomposição ontológica, acréscimo ou decréscimo de ser, na terminologia de Gadamer, nos mostram o intérprete tem papel decisivo na sua lida com a tradição. O intérprete é aquele que recepciona a tradição, mas também é o encarregado de manter viva a sua própria possibilidade ao se indagar sempre acerca da coisa em questão no processo interpretativo. Quando o intérprete indaga à coisa o que ela é, o índice remissivo da imagem se posiciona, apresenta-se e orienta o diálogo do intérprete com a tradição. Por isso, a tarefa da interpretação é sempre marcada por uma certa philya pelas coisas em questão, e justamente por ser philya e não submissão, o intérprete pode emprestar voz à tradição para que ela se diga de outras maneiras, articule o seu ser de dentro para fora: ou seja, ela só experimenta o seu diverso na sua relação com o mesmo. A fusão de horizontes em Gadamer nos evidencia que o movimento da tradição é sempre um automovimento, e quanto mais se confronta o caráter de entrega da história efeitual, mais ela é reforçada no caráter fático, da factidade que é a dela. Em suma: a experiência da diferença, do diverso, da negação, é somente possível pela 
afirmação, pela posição, pela identidade, o que demonstra a importância de Platão e de Hegel para Gadamer.

Contudo, o que marcadamente nos compete nesse instante, é justamente perceber que essa experiência hermenêutica tradicional em Gadamer envolve uma dimensão temporal de fundo: o ser dos construtos de sentido historicamente constituídos é temporal porque ele precisa da dissolução, da diferença, para adquirir sua identidade. Para Gadamer, esse fenômeno é melhor percebido no interior da experiência estética, do modo de ser da obra de arte, pois a ontologia da obra de arte é paradigmática para a história efeitual, ou seja, o que acontece no campo de realização artístico se repete no interior da dinâmica da história e da interpretação. Por isso é preciso que olhemos mais de perto o modo de ser da obra de arte em Gadamer, que ostenta três características fundamentais: obra de arte é jogo, símbolo e festa.

Gadamer pensa a obra de arte em meio ao seu processo de vir-a-ser obra. Com base em A origem da obra de arte, texto heideggeriano da década de 1930 (HEIDEGGER, 2002), Gadamer realça que, no interior da experiência estética, o que é realmente relevante não é aquilo que eu, observador, experimento com ela, mas sim o que, através da abertura do mundo da obra, realiza-se enquanto obra de arte. Essa estrutura objetiva e fenomenológica da constituição artística, que demonstra a co-originariedade da relação entre apresentação e aquilo que se apresenta, é paradigmática para a verdade dos processos históricos, uma vez que essa estrutura hermenêutica é universal, e é descrita por Gadamer (2011, p. 155 [107/8]) através da noção de jogo, que significa a extensão do campo de formação da obra à história.

Jogo é uma expressão que Gadamer retira de Huizinga para acentuar o fato de que, quando o jogo se instaura, o sujeito do jogo não são os jogadores que dele participam, mas o jogo ele mesmo, que tanto é melhor jogado quando os seus participantes são absorvidos em seu campo: "É o jogo que é jogado ou que se desenrola como jogo; não há um sujeito fixo que esteja jogando ali. O jogo é a realização do movimento como tal” (GADAMER, 2011, p. 156 [109]). O jogo sempre é autoapresentação do jogado. Quando há o acontecimento do campo de jogo de uma obra de arte, através da apresentação o apresentado aparece ao ponto de absorver, na mediação, aquele que apresenta (GADAMER, 2011, p. 162 [114]). Isso quer dizer que há figuras, imagens ou construtos do jogo que aparecem em meio ao espaço aberto pela apresentação. Assim, não há imagem da arte, construto, sem a apresentação, da mesma maneira que a apresentação é sempre apresentação da imagem da obra. Nota-se, assim, a relação 
intencional entre apresentação e apresentado, e nessa relação a imagem da obra constitui o seu ser.

Gadamer pretende realçar a relação indissociável entre a apresentação da obra e a constituição do seu próprio ser, o que implica em dizer que não há obra para além do seu acontecimento, da sua aparição ou exposição, fazendo a obra e sua interpretação consentâneas. Do que acabamos de afirmar, pode-se depreender que a interpretação do espectador é fundamental para o acontecimento do próprio ser da obra. $\mathrm{O}$ espectador, assim, não é elemento estranho à obra, pelo contrário, é convidado pelo próprio campo da arte a junto dela permanecer, e é nesse encontro, nunca definitivo (GADAMER, 2011, p. 152 [105]), diga-se, que se forma o ser da obra de arte: há uma relação indissociável entre visão e imagem que se repete sempre a cada novo encontro (GADAMER, 2010, p. 178). A interpretação ou a participação é consentânea à formação do ser da obra, e é a participação a responsável por permitir que o próprio ser da obra se institua, porque ser, em Gadamer, é simbólico: o acontecimento estético, assim como qualquer mediação histórica, dada a natureza universal da hermenêutica, é símbolo, querendo com isso ressaltar o caráter daquilo que não pode se constituir a não ser na relação com um outro. Símbolo é uma palavra de origem grega que quer dizer tábua de recordação tessera hospitalis. Um anfitrião quebrava essa tábua em duas partes, e oferecia ao hóspede uma delas que para, em trinta ou cinquenta anos, pudesse ser identificada a sua volta ou a chegada de um descendente. É por meio do símbolo que se reconhece um antigo conhecido. Gadamer, ao apresentar a origem histórica do simbólico na reunião do fragmento da tessera hospitalis grega, ressalta o fato de que a totalidade do ser depende da requisição da parte co-pertencente, ou, em outros termos, que a constituição do ser de algo depende da relação com o outro (GADAMER, 2010, p. 173). É isso que o simbólico demonstra: a natureza de co-pertencimento necessário. No caso da obra de arte, a interpretação ou participação se faz necessária para a continuidade do processo de articulação da voz da obra porque, no momento em que se produz ou posiciona a obra, ela passa a se autonomizar do seu autor.

Todavia, para que a articulação simbólica se desenvolva em toda sua potencialidade, é preciso que a outra dimensão do símbolo também ganhe corpo. De uma maneira ainda mais clara, a interpretação não só traz à presença de forma incólume a obra, como também a atualiza ou permite a sua reconfiguração ou sua alteração. Isso faz com que a interpretação possibilite acréscimo de ser ao construto, que se transforma em meio à interpretação. Uma execução de uma partitura clássica pode receber uma interpretação revolucionária que marca, a partir daí, 
uma nova voz da música. Portanto, o ser da obra não é para além da apresentação, pois o apresentado sofre acréscimo de ser ou transformação em meio à apresentação. Por outro lado, não quer isso dizer que o intérprete conceda uma nova voz ao construto - na verdade, é ele, construto, que experimenta uma nova configuração em si através da apresentação. Gadamer denomina esse acento da diferenciação da obra de metamorfose do construto (GADAMER, 2011, p. 168 [118]). A metamorfose do construto refere-se ao fato de que a configuração da obra experimenta uma alteração radical em sua estrutura ao ponto de deixar de ser aquilo que era para se tornar outra coisa. Com a metamorfose do construto, que faz com que a obra experimente novas configurações, encontra-se em jogo outro elemento platônico extremamente marcante no pensamento gademeriano - a relação entre unidade e multiplicidade. O que caráter simbólico acentua é precisamente a necessidade da mediação com o outro para a constituição da mesmidade: a obra requisita sua diferenciação para ela seja ela mesma. E essa diferenciação é diferenciação no tempo, temporal. O ser da obra é ser temporal (GADAMER, 2011, p. 181 [128]), que somente é em se diferenciando, sob pena de obra ser um eterno ter-sido.

A temporalidade da arte, verdadeira condição de possibilidade de constituição do seu ser, é expressa por Gadamer (2011, p. 180; GADAMER, 2010, p. 180) na noção de festa, a retomada temporal da coisa em sua diferenciação. A temporalidade da obra não é a da permanência no tempo, da identidade plena em meio ao devir - ser temporal em Gadamer é aquele que somente é em sendo diferente. É ele o mesmo em sua diferença. Daí se dizer que a sua temporalidade não é a da sucessão no tempo, mas sim a da retomada da celebração festiva (GADAMER, 2010, p. 182). Por que Gadamer se vale aqui da expressão festa para marcar a temporalidade do ser? Pelo fato de que, no interior da festa, há sempre a retomada do celebrado, mesmo que a celebração seja diversa. Quando se celebra uma festa em uma data ou ocasião específica, um aniversário de um amigo, por exemplo, naquela mesma data, que é retomada em todos os anos, revive-se a celebração do nascimento, mesmo que as festas de aniversário sejam, a cada ano, diferentes. O que acontece no interior da celebração da festa, é a retomada do encontro festivo, que se institui em meio à diferença temporal de cada festa anual - as pessoas que comparecerão em todos os anos não serão necessariamente as mesmas, mas o celebrado sempre é, e, a cada vez em que se celebra, marca-se a data de nascimento, que é sempre ela mesma em todos os anos, de uma forma diversa. Por isso se diz que não se repete a festa, mas se retoma ou se celebra novamente o acontecimento festivo. 
No interior da retomada da celebração festiva, observa-se uma modalidade específica e peculiar de tempo. Há duas experiências fundamentais do tempo, para Gadamer (2010, p. 183). O tempo da celebração festiva não é o tempo de disposição, calculado ou empregado, tempo para algo, marcado pela sucessão ou soma de intervalos menores, o tempo de que se dispõe, que se tem ou não se tem, que precisa ser preenchido com a inserção de algo, que, quando não se dá, leva ao aborrecimento ou ao tédio diante sua não-satisfação, pois é sempre tempo planejado. O tempo festivo é o tempo pleno, próprio, completamente preenchido, como, por exemplo, na lembrança de momentos marcantes da infância ou da juventude, que subitamente se instaura (GADAMER, 2010, p. 184-5) e nos arrebata. A temporalidade característica da festa, que reflete o modo de ser da obra de arte, é aquela que é capaz de mediar com precisão unidade e multiplicidade, presença e alternância, sobretudo, eternidade e mutação temporal - é o tempo do instante, que se estabelece pela sua constante retomada. Na festa, a celebração retoma o instante do celebrado e o revivifica aqui e agora mais uma vez. Não se trata de uma mera repetição daquilo que foi: o múltiplo, o diverso, aparece em articulação com o uno - o fugidio encontra-se em conexão com o eterno. O que a retomada da interpretação simbólica faz, ao celebrar o instante festivo da obra, é zelar, garantir a possibilidade de manutenção do próprio ser da obra, que se mantém nas diversas articulações possíveis de sua voz.

A retomada é característica temporal tanto do fenômeno estético quanto do próprio acontecimento hermenêutico da história efeitual. Assim como as imagens da obra pautam o acontecimento estético, a tradição orienta a interpretação, e a retomado do fenômeno hermenêutico que garante a própria possibilidade da ulterior característica de entrega da tradição.

\section{CONCLUSÕES}

Para que a história do direito tenha condições de realizar não só a apresentação de seus temas e de suas questões de maneira metodologicamente adequada, mas também possa contribuir para a realização da historicidade, ou da articulação temporal do fundamento do direito, é necessário que ela ultrapasse as fronteiras de uma teoria rumo à filosofia. Por meio de nossa proposta de trabalho, acreditamos que a fenomenologia, por acompanhar detidamente o que aparece por si mesmo, a partir de si mesmo, em seu campo de automostração, poderia contribuir para a historicidade do ser do direito por meio da hermenêutica gadameriana. Isso 
porque a hermenêutica filosófica, ao deixar claro na chamada fusão de horizontes, que a interpretação, ao mesmo tempo que fomenta a atualização da coisa em questão no discurso, permite que o próprio ser da coisa se reformule ou receba acréscimo em sua estrutura ontológica no processo. Tal retomada interpretativa concede unidade e multiplicidade, identidade e diferença, ao ser do interpretado, como se nota nas noções de jogo, símbolo e festa, presentes em Gadamer. A hermenêutica filosófica, uma vez transposta ao discurso do historiador do direito, principalmente para a teoria da fontes, possibilitaria que a normatividade jurídica fosse desenvolvida para além de textos jurídicos, e também acentuaria o papel da doutrina jurídica como fonte de destaque do direito, uma vez que o discurso interpretativo não apenas comentaria textos, mas rearticularia, no presente, o fundamento da juridicidade.

\section{REFERÊNCIAS BIBLIOGRÁFICAS}

ARAÚJO, João Paulo Medeiros. A justiça e a lei no horizonte da técnica: contribuições para uma fenomenologia do direito. Tese de doutoramento. Belo Horizonte: Faculdade de Direito da UFMG, 2018. 89 p.

ARENDT, Hannah. Entre o passado e o futuro. Trad. Mauro W. Barbosa. São Paulo: Perspectiva, 2014.

BERMAN, Harold. Direito e Revolução. A formação da tradição jurídica ocidental. Trad. Eduardo Takemi Kataoka. São Leopoldo: Editora Unisinos, 2006.

BOBBIO, Norberto. O Positivismo Jurídico. Lições de Filosofia do Direito. Trad. Márcio Pugliese, Edson Bini, Carlos E. Rodrigues. São Paulo: Ícone, 1995.

Teoria do ordenamento jurídico. Trad. Maria Celeste Cordeiro Leite dos Santos. 6. ed. Brasília: Editora UnB, 1995.

CAENEGEM, R. C. van. Uma Introdução Histórica ao Direito Privado. Trad. Carlos Eduardo Lima Machado. 2. ed. São Paulo: Martins Fontes, 2000.

CASANOVA, Marco Antonio. Apresentação a Dilthey. In: DILTHEY, Wilhelm. A construção do mundo histórico nas ciências humanas. Trad. Marco Antonio Casanova. São Paulo: Unesp, 2010.

Janeiro: Viaverita, 2013.

Eternidade Frágil. Ensaio de Temporalidade na Arte. Rio de Mundo e historicidade: leituras fenomenológicas de Ser e tempo. v. 01 - Existência e Mundaneidade. Rio de Janeiro: Viaverita, 2017. 
de Friedrich Nietzsche. Rio de Janeiro: Forense, 2003.

. O Instante Extraordinário. Vida, História e Valor na Obra . "Pensamento em transição". Heidegger e o "outro início" da filosofia. In: CASANOVA, Marco Antonio; MELO, Rebeca Furtado (Orgs). Fenomenologia Hoje IV. Fenomenologia, Ciência e Técnica. Rio de Janeiro: Viaverita, 2013.

COSTA, Pietro. Soberania, Representação, Democracia. Ensaios de História do Pensamento Jurídico. Trad. Alexandre Rodrigues de Castro et alli. Curitiba: Juruá, 2010.

DAL RI JÚNIOR, Arno. Apresentação, In: GROSSI, Paolo. O Direito entre Poder e Ordenamento. Trad. Arno Dal Ri Júnior. Belo Horizonte: Del Rey, 2010.

DILTHEY, Wilhelm. A construção do mundo histórico nas ciências humanas. Trad. Marco Antonio Casanova. São Paulo: Unesp, 2010.

DUVE, Thomas. História do Direito Europeu - perspectivas globais. Trad. Walter Guandalini Júnior. In: Revista da Faculdade de Direito da UFPR. Curitiba, v. 60, n. 03, set./dez./ 2015, p. 383-412.

FIGAL, Günther. Introdução a Martin Heidegger. Trad. Marco Antonio Casanova. Rio de Janeiro: Viaverita, 2016.

Martin Heidegger: Fenomenologia da liberdade. Trad. Marco Antonio

Casanova. Rio de Janeiro: Forense Universitária, 2005.

FONSECA, Ricardo Marcelo. Introdução teórica à história do direito. Curitiba, Juruá, 2012.

GADAMER, Hans-Georg. A Atualidade do Belo. Arte como Jogo, Símbolo e Festa. In:

GADAMER, Hans-Georg. Hermenêutica da Obra de Arte. Trad. Marco Antonio Casanova. São Paulo: Martins Fontes, 2010.

. Verdade e Método I: traços fundamentais de uma hermenêutica filosófica. Trad. Flávio Paulo Meurer. 11. ed. Petrópolis: Vozes; Bragança Paulista: Editora São Francisco, 2011.

GOYARD-FABRE, Simone. Os fundamentos da ordem jurídica. Trad. Claudia Berliner. São Paulo: Martins Fontes, 2007.

GRONDIN, Jean. Introdução à Hermenêutica Filosófica. Trad. Benno Dischinger. São Leopoldo: Unisinos, 1999.

GROSSI, Paolo. A ordem jurídica medieval. Trad. Denise Rossato Agostinetti. São Paulo: Martins Fontes, 2014.

HEGEL, G. W. F. Fenomenologia do Espírito. Trad. Trad. Paulo Meneses. 7. ed. Petrópolis/Bragança Paulista: Vozes/Universitária São Francisco, 2012. 
HEIDEGGER, Martin. A origem da obra de arte. Trad. Irene Borges-Duarte e Filipa Pedroso. Caminhos da Floresta. Trad. Irene Borges-Duarte, Filipa Pedroso, Alexandre Franco de Sá, Hélder Lourenço, Bernhard Silla, Vitor Moura e João Constâncio. Lisboa: Fundação Calouste Gulbenkian, 2002.

Contribuições à filosofia: do acontecimento apropriador. Trad.

Marco Antonio Casanova. Rio de Janeiro: Viaverita, 2015.

Os conceitos fundamentais da Metafísica. Mundo - Finitude -

Solidão. Trad. Marco Antonio Casanova. 2. ed. Rio de Janeiro: Grupo Gen/Forense Universitária, 2011.

$\overline{\text { Vozes/Unicamp, } 2012 .}$

Ser e tempo. Trad. Fausto Castilho. Petrópolis/Campinas:

Sobre a essência do fundamento. In: HEIDEGGER, Martin.

Conferências e escritos filosóficos. Trad. Ernildo Stein. São Paulo: Abril Cultural, 1979.

HERRERO, Javier. Religião e História em Kant. Trad. José A. Ceschin. São Paulo: Loyola, 1991. p. 139.

HESPANHA, António Manuel. Cultura Jurídica Europeia. Síntese de um Milênio. Florianópolis: Fundação Boiteaux, 2005.

HUSSERL, Edmund. A ideia da fenomenologia (cinco lições). Lisboa: Edições 70, s/d.

Investigações Lógicas. Investigações para a Fenomenologia e a Teoria do Conhecimento. Trad. Pedro Alves e Carlos Aurélio Morujão. Rio de Janeiro: Grupo Gen/Forense Universitária, 2012.

KANT, Immanuel. A Paz Perpétua. Um Projecto Filosófico. Trad. Artur Morão. Covilhã: Universidade Beira do Interior, 2008.

Crítica da Razão Pura. Trad. Manuela Pinto dos Santos e Alexandre Fradique Morujão. Lisboa: Fundação Caloute Gulbenkian, 1985.

Lisboa: Edições 70, 2008.

Fundamentação da Metafísica dos Costumes. Trad. Paulo Quintela.

Idéia de uma história universal do ponto de vista cosmopolita. Trad.

Rodrigo Naves e Ricardo R. Terra. 2. ed. São Paulo: Martins Fontes, 2004.

O Conflito das Faculdades. Trad. Artur Morão. Lisboa: Edições 70,

1993.

. Resposta à Pergunta: O que é o Esclarecimento? In: O que é o

Esclarecimento? Trad. Paulo Cesar Gil Ferreira. Rio de Janeiro: Viaverita, 2011. 
KELLY, John M. Uma breve história da teoria do direito ocidental. Trad. Marylene Pinto Michael. São Paulo: Martins Fontes, 2010.

KOSELLECK, Reinhart. Estratos do tempo. Trad. Markus Hediger. Rio de Janeiro: Contraponto, 2014.

LIMA VAZ, Henrique Cláudio de. A significação da Fenomenologia do espírito. Apresentação a HEGEL, G. W. F. Fenomenologia do Espírito. Trad. Trad. Paulo Meneses. 7. ed. Petrópolis/Bragança Paulista: Vozes/Universitária São Francisco, 2012.

LÖWITH, Karl. O Sentido da História. Trad. Maria Georgina Segurado. Lisboa: Edições 70, 1991.

MELO, Rebeca Furtado de (Orgs.). Fenomenologia Hoje IV. Fenomenologia, ciência e técnica. Rio de Janeiro: Via Verita, 2013.

MERLEAU-PONTY, Maurice. Fenomenologia da percepção. Trad. Carlos Alberto Ribeiro de Moura. 4. ed. São Paulo: Martins Fontes, 2015.

NIETZSCHE, Friedrich. O nascimento da tragédia: ou helenismo e pessimismo. Trad. J. Guinsburg. 2. ed. São Paulo: Companhia das Letras, 1992.

. Segunda Consideração Intempestiva. Da utilidade e desvantagem

da história para a vida. Trad. Marco Antônio Casanova. Rio de Janeiro: Relume Dumará, 2003.

NUNES, Benedito. História e ontologia (Da essência da técnica), In: CASANOVA, Marco Antônio; MELO, Rebeca Furtado (Orgs). Fenomenologia Hoje IV. Fenomenologia, Ciência e Técnica. Rio de Janeiro: Viaverita, 2013.

OLIVEIRA, Paulo César Pinto de. Filosofia do direito e hermenêutica filosófica. Do caráter hermenêutico da filosofia do direito. Rio de Janeiro: Viaverita, 2019.

REIS, José Carlos. A História entre a Filosofia e a Ciência. 3. ed. São Paulo: Autêntica, 2004.

Wilhelm Dilthey e a autonomia das ciências histórico-socias. Londrina:

Editora da Universidade Estadual de Londrina, 2003.

SALGADO, Joaquim Carlos. A Idéia de Justiça em Hegel. São Paulo: Loyola, 1996.

A idéia de justiça no mundo contemporâneo. Fundamentação

e aplicação do Direito como Maximum ético. Belo Horizonte: Del Rey, 2006.

SAVIGNY, Friedrich Karl von. De la Vocacion de Nuestro Siglo para la Legislacion y la

Ciencia del Derecho. Trad. Adolfo G. Posada. Buenos Aires: Editorial Atalaya, 1946. 
Sistema del derecho romano actual. Trad. Jacinto Mesía y

Manuel Poley. Tomo I. Madrid: F. Góngora y Companía Edictores, 1878.

SCHIOPPA, Antonio Padoa. História do Direito na Europa. Da Idade Média à Idade Contemporânea. Trad. Marcos Marcionilo e Silvana Cobucci Leite. São Paulo: Martins Fontes, 2014.

ZAHAVI, Dan. Fenomenologia para iniciantes. Trad. Marco Casanova. Rio de Janeiro, Viaverita, 2019.

Trabalho recebido em 30 de abril de 2020

Aceito em 05 de dezembro de 2020 